\title{
Breakthroughs towards a malaria vaccine ${ }^{1}$
}

\author{
Avanços rumo à vacina contra a malária
}

\section{Ruth Sonntag Nussenzweig}

Pesquisadora da Langone Medical Center, New York University.

550 First Avenue, room 131MSB Medical Science Building

10016 - New York - NY - USA

Ruth.Nussenzweig@nyumc.org

Introduction by/ Apresentação de Antoniana U. Krettli

Pesquisadora do CNPq no Laboratório de Malária/Instituto René Rachou/Fundação Oswaldo Cruz.

Avenida Augusto de Lima, 1715 30190-002 - Belo Horizonte - MG - Brasil

akrettli@cpqrr.fiocruz.br
NUSSENZWEIG, Ruth Sonntag. Breakthroughs towards a malaria vaccine. História, Ciências, Saúde - Manguinhos, Rio de Janeiro, v.18, n.2, abr.-jun. 2011, p.559-564

\section{Abstract}

Since the 1960s, the scientist Ruth Nussenzweig, C.V. Starr Professor at New York University School of Medicine, has been working to develop an antimalarial vaccine. In her testimony, she traces some of the stages through which her research has passed. At the beginning of her studies, most scientists held that it would be impossible to develop such a vaccine. However, a different opinion had been expressed in a paper on avian malaria written some forty years earlier by a British researcher and his collaborators from India. The immunization principle developed by this group was irradiation of sporozoites in order to deactivate the parasite that causes malaria. Ruth Nussenzweig revived and expanded upon this line of research, which now underpins her efforts to devise an antimalarial vaccine for human use. Keywords: immunology; parasitology; malaria; vaccine; Ruth Nussenzweig.

\section{Resumo}

Desde a década de 1960, a cientista Ruth Nussenzweig, titular da cátedra C.V. Starr da New York University School of Medicine, pesquisa o desenvolvimento de uma vacina contra malária. Em depoimento, ela retraça algumas das fases pelas quais passou a pesquisa. No início dos estudos, a posição prevalente entre cientistas era a de que não seria possível desenvolver essa vacina. Posição divergente encontrava-se em um trabalho sobre malária aviária, feito quarenta anos antes, por um pesquisador inglês e colaboradores indianos. O princípio da imunização desenvolvido por esse grupo estava na inativação do parasita que causa a malária, por meio da irradiação dos esporozoítos. Essa linha de pesquisa, retomada e ampliada por Ruth Nussenzweig, é a base sobre a qual ela desenvolve seus estudos para a elaboração da vacina contra a malária em seres humanos.

Palavras-chave: imunologia; parasitologia; malária; vacina; Ruth Nussenzweig. 
B orn in Vienna, Austria, on June 20th, 1928, Ruth was still a child when she reached São Paulo, Brazil, in 1939, with her parents, fleeing the Nazi regime during the Second World War. Her parents were both doctors and she had only one (younger) brother. She spent the rest of her youth in São Paulo, where she studied medicine at the University of São Paulo (USP), the largest university in Latin America. It was then, in the late 1940's, that, she and Victor Nussenzweig met; when both were medical students there (Figure 1). In the second year of her studies she convinced Victor to work with research. They went to ask for help from Professor Samuel B. Pessoa, an eminent scientific and political leader who was head of a research group at the Department of Parasitology, USP. His group was flourishing then and other names from that time would subsequently become international scientific authorities. ${ }^{2}$ Ruth and Victor got married in 1953 and celebrated the occasion in the university library with Samuel Pessoa and others. In 1958 she went to Collège de France as Post-Doctoral Fellow, and in 1965 she moved to the United States to join the faculty at the New York University (NYU) School of Medicine.

When Ruth and Victor Nussenzweig entered the science world during medical school, their intention was to find a cure for cancer through the use of Trypanosoma cruzi, the agent of American trypanosomiasis, also known as Chagas disease. They had come across an article which reported on two Russian scientists who had used this approach with success. Although they failed to reproduce the reported findings, this was the starting point for the important discovery that $T$. cruzi trypomastigotes were killed by gentian violet. This observation was the basis for the use of the drug in preventing the transmission of Chagas disease by blood transfusion. Ruth and Victor have worked together since then, life partners, close friends, and the proud parents of three children born in São Paulo, all doctors: Michel, MD, PhD, a researcher at the Rockefeller University; Sonia, PhD, working in the School of Preventive Medicine of the University of São Paulo; and Andre, PhD, working at the US National Cancer Institute, National Institutes of Health.

In the 1960's, while working at the NYU School of Medicine on a malaria vaccine, Ruth decided to initiate a research project introducing first the rodent, then the simian model of malaria, using a naturally infected Saimiri monkey that had been found in a forest near São Paulo city. Ruth's dreams of finding a vaccine had no limits.

\footnotetext{
${ }^{1}$ Testimony by Doctor Ruth Nussenzweig, given during the award ceremony at the seminar "Henrique Aragão e a pesquisa sobre a malária: 100 anos da descoberta do ciclo exoeritrocítico da malária" (Henrique Aragão and malaria research: 100 years since the discovery of malaria's exoerythrocytic cycle), held at the Oswaldo Cruz Foundation in April 2007. Doctor Nussenzweig received an Henrique Aragão Medal, named in honor of the Brazilian researcher who, like Doctor Nussenzweig, blazed new trails in malaria studies.

${ }^{2}$ Besides the Nussenzweigs, the same group included: Professor Michel Rabinovich, a former prominent scientist at New York University's Pathology Department, head of the Parasitology group at the Pasteur Institute in the 1980's, who currently works at Escola Paulista de Medicina; Professor Luiz Hildebrando Pereira da Silva, a professor at USP during the 1950's, researcher at CNRS and Institut Pasteur, in Paris, and current head of the Institute of Tropical Disease Research at the Federal University of Rondônia, where he researches immunology and epidemiology of malaria; and Professor Erney Plessman Camargo, former head of the Parasitology Department at USP and former president of the National Research Council (Conselho Nacional de Desenvolvimento Científico e Tecnológico - CNPq).
} 
The Saimiri monkey had been naturally infected with Plasmodium brazilianum, a vivaxlike malaria parasite. It was captured with the help of Professor Leonidas Deane's contacts in São Paulo, who had been working for several years with simian malaria. He strongly believed these animals were carriers of human malaria. He arranged for the infected Saimiri to be taken to Rio de Janeiro and I transported the monkey to USA. Both Professor Deane and Professor Brener convinced me to work with Ruth at NYU on the malaria vaccine project, a rather unique opportunity for my career. So I applied for the vacancy opened by Ruth at NYU, and got a Pan American Health Organization fellowship. I am sure it was quite a wise decision which changed my life. Ruth changed the way I looked at science, and opened the way for several of her former students to enter the malaria vaccine world, which shows a level of generosity uncommon for that field of research!

\section{Early breakthrough papers by Ruth's New York University group}

At NYU, Ruth and her co-workers were the first to describe the course of sporozoiteinduced infections of rodent malaria and the protection conferred to mice after being

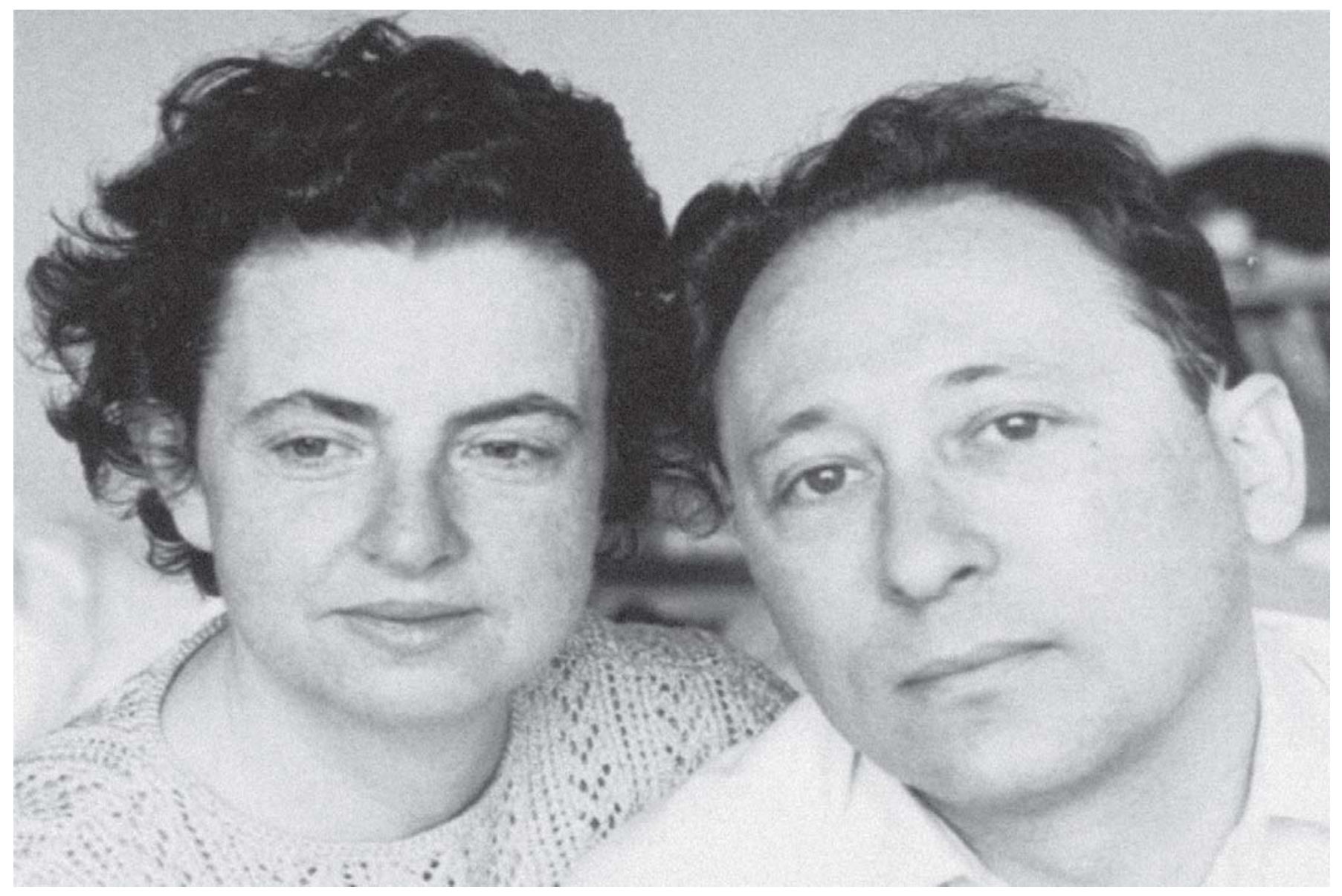

Figure 1: Ruth and Victor Nussenzweig 
immunized with inactivated sporozoites, after showing how to infect mosquitoes with these parasites.

After showing that attenuated sporozoites induced full protection against malaria in the mammalian host, Ruth, her husband Victor and their students studied the surface of the malaria sporozoites using parasites from rodents, human and non-human primates, and showed that they are covered by the major circumsporozoite (CS) protein, an important finding which led to further studies in which many groups participated.

Another very important finding of the group was the cloning and sequencing of the CS protein, first in simian malaria parasites, Plasmodium knowlesi. This work was followed by the simultaneous cloning, at NYU and NIH, of the CS from P. falciparum, and its sequencing. The way was opened for the production of the CS protein as a recombinant (rCS) protein on a routine basis, which facilitated many approaches in epidemiological studies of populations exposed to the malaria sporozoite.

An enormous bulk of work has been done on monoclonal antibodies and other tests, aiming to elucidate how sporozoites penetrate and develop in liver hepatocytes, how they enter and traverse macrophages and other cells, as first shown by the NYU group. Recent breakthroughs in genetics that shed light on the role of CS in the malaria cycle, expanded this information, as shown mainly by groups working on rodent malaria at the Pasteur Institute in France. ${ }^{3}$

No doubt, Ruth has completely changed the approach to malaria vaccine research using sporozoites attenuated by irradiation, having influenced many people worldwide and continuing to do so.

There are over sixty different vaccines being tested for malaria in humans, of which $60 \%$ include the sporozoite surface antigens inspired by the work developed at NYU. If a vaccine ever becomes available for mass use, the world will have to acknowledge Ruth and her leadership during a lifetime working on the problem. I am indebted to her and whenever possible I make this clear; she was the most important mentor I have ever had and opened many doors and made accessible several collaborations, including that of Victor, in the early seventies, when we showed the basis of malaria immunosuppresion for the first time. ${ }^{4}$

Antoniana U. Krettli

CNPq Fellow at the Laboratório de Malária/ Instituto René Rachou/Fundação Oswaldo Cruz

\section{$\rightarrow \rightarrow \rightarrow<<$}

\footnotetext{
${ }^{3}$ Menard, R. et al. Circumsporozoite protein is required for development of malaria sporozoites in mosquitoes. Nature, London, n.385, p.336-340, 1997; Amino, R. et al. Imaging malaria sporozoites in the dermis of the mammalian host. Nature protocols, London, v.2, n.7, p.1705-1712, 2007.

${ }^{4}$ Krettli, Antoniana; Nussenzweig, Ruth. Depletion of T and B lymphocytes during malaria infections. Cellular Immunology, Seattle, n.13, p.440-446, 1974; Krettli, Antoniana; Nussenzweig, Victor; Nussenzweig, Ruth. Complement Alterations in Rodent Malaria. American Journal of Tropical Medicine and Hygiene, Deerfield, n.25, v.1, p.34-41, 1976.
} 


\section{Depoimento de Ruth Sonntag Nussenzweig}

In 1965, when I started to work and publish on malaria in New York (at New York University School of Medicine), the general view of malaria researchers and sponsoring institutions (such as the World Health Organization - WHO) was that there was no chance of finding a vaccine to protect against the disease. This view was based on the fact that individuals living in malaria-endemic areas have malaria many times, and thus do not develop protective immunity. There was an additional argument (which I heard many times) that it was not possible to outdo nature.

When I started to work on malaria, I already had a background in immunology, but I had never come across any reference to immunization against malaria. The only exception was a manuscript by a British investigator with Indian collaborators published about forty years earlier. They had used avian malaria, which has a very different life cycle from mammalian malaria, which occurs in rodents, monkeys and humans.

They observed that exposure of sporozoites (invasive stage) to ultraviolet rays resulted in the loss of their infectivity in ducks. (If not inactivated, this malaria infection killed ducks, their experimental animals.) However, this activation did not result in any loss of immunogenicity of the sporozoites. Ducks injected repeatedly with ultraviolet-exposed parasites became resistant to infection with untreated, fully virulent sporozoites. There had been no other publications on the subject in the forty years between their report and my experiments in 1965.

I tried to inactivate sporozoites of mammalian (rodent) malaria that were available in my department. I used X-rays, which could more easily be quantified than ultraviolet exposure. Then I injected the attenuated, irradiated sporozoites repeatedly into mice. These animals were subsequently challenged with untreated, fully invasive sporozoites. The result was that the animals were protected, i.e. they did not develop the malaria infection.

I did this experiment using various rodent malaria species available in the department, namely Plasmodium berghei, $P$. yoelii, and P. chabaudi. The results were the same in every case, namely, complete protection against viable sporozoite challenge of the corresponding rodent malaria species.

This protective immunity was only effective against sporozoite-induced infections; it had no protective effect against blood-stage infection. After our publication on rodent immunization and protection in mice, we attempted to immunize monkeys with irradiated sporozoites of monkey malaria (P. cynomolgi or P. knowlesi). The results were similar i.e. protective immunity was confirmed.

In view of these experimental results, I discussed with Doctor Philip K. Russell (head of the Walter Reed Army Institute of Research) about how to design a human trial. I mentioned that it would have to involve human volunteers being bitten by a large number of mosquitoes infected with irradiated $P$. falciparum. The mosquitoes were not affected by the irradiation, but being $P$. falciparum infected, the parasites which they contained were susceptible to the irradiation and were attenuated. The human volunteers would have to 
be bitten by large numbers of these infected, irradiated mosquitoes and the procedure would have to be repeated very many times in order to boost the immune response.

The vaccination trial I planned with Doctor Russell was first put into practice on prisoners, but as I was a woman I could not enter the prison, so only Doctor Vanderberg, a colleague from my department, participated in the trial, monitoring its results.

Since sporozoites cannot be grown in vitro (where they do not multiply), they could only be obtained by the laborious dissection of infected mosquito salivary glands. Therefore, this vaccine trial in human volunteers could only be done on a small number of individuals, not in large malaria-endemic areas. It was only a demonstration of the principle that protection can be obtained by vaccination. All the few individuals vaccinated by the bites of infected, irradiated mosquitoes were protected against challenge with fully invasive sporozoites. This was demonstrated by the inoculation of non-immunized volunteers, who all got the infection and were immediately treated. They used a chloroquine-sensitive strain of $P$. falciparum.

Moreover, the vaccinated volunteers were protected not only against the $P$. falciparum strain used for their vaccination, but also against $P$. falciparum sporozoites received from different countries. They were not protected against blood-stage infection, as previously observed in mice. In other words, the protection was stage specific.

The currently used vaccine, RTS,S contains a large portion of the CS protein plus adjuvants, is undergoing the final phase III in individuals of various age groups in different areas of Africa. The protection was between $30-50 \%$ in previous human trials in endemic areas. In addition, there was a decrease in the number of very severe malaria infections in vaccinated individuals. However, RTS,S only protects against reinfection for about 18 months. More importantly RTS,S has to be boosted twice. This is not practical in malariaendemic areas, since individuals have to return to the health center where the vaccine IS administered.

Ideally, a sub-unit vaccine against malaria should be effective after a single shot. I tried this using a virus, the yellow fever vaccine virus, which was engineered to express a key portion of the CS-protein of $P$. berghei, which only infects rodents. I forgot to mention earlier that the CS-protein is a major abundant immunodominant sporozoite surface antigen, which is also present in the early liver stage.

When this recombinant yellow fever vaccine virus was injected into mice just once, it elicited about $70 \%$ protection. However, this was done in mice and with rodent malaria. It needs to be repeated with $P$. falciparum in humans, but for technical reasons this is very, very difficult to achieve.

Presently, Victor and I are helping doctor Maurício Rodrigues develop a vaccine against $P$. vivax based on its CS proteins. P. vivax is prevalent in the Amazon region, in Central America and Asia. It is increasingly virulent and there are already reports of drug-resistance. 